\title{
New religious movement responses to COVID
} Frame alignment strategies and social context

$\mathrm{N}$ ew religious movements (NRMs) have responded to the COVID-19 pandemic in diverse ways, ranging from closely following mainstream public health recommendations to explicit rejection of such guidance. This article considers the manner in which NRMs have responded to the pandemic through analysis of groups' ideological alignment with their host societies' cultural and social frames. Extending the Bromley-Melton (2012) model of social alignment and the Rochford (2018) approach of frame alignment, the response of these NRMs must be contextualized in regard to alignment with broader social frames. The article considers specific cases of NRMs in South Korea, India, and the United States and posits that no single model can encompass NRM responses to the pandemic, but that multiple social factors provide guidance for understanding why and how NRMs responded to the COVID-19 pandemic.

\section{Introduction}

The early days of the COVID-19 pandemic coincided with the Gaura Purnima festival, one of the holiest and most important of the yearly festivals for devotees of the International Society for Krishna Consciousness (ISKCON), also called the Hare Krishna movement. The holiday recognizes the birth of the founder of the movement's lineage, the fifteenth-century Hindu reformer Chaitanya, whom ISKCON devotees consider to be an incarnation of the divine, and the veneration of whom

\author{
Atribution 4.0 International (CCBY 4.0)
}

VERTAISARVIOITU

KOLLEGIALT GRANSKAD

PEER-REVIEWED

marks this movement as distinct from other forms of Hindu tradition. The festival is normally one of the busiest at many ISKCON temples, with day-long rounds of chanting, singing, lectures and classes, and a culminating feast. It was always a major highlight at the North American ISKCON temple where I engaged in ethnography several decades ago. The Gaura Purnima festival builds on weeks of preparation and planning, ranging from a spring clean of the physical temple facilities to the cooking and presentation of elaborate meals for the deities and their devotees. So I was surprised on 7 March 2020 when I saw an announcement from the temple asking devotees to consider attending virtually that year, and noting that anyone who had travelled recently ought to self-quarantine. '[While] we fully realize that Lord Krishna is in control of everything, we also must take a realistic and responsible approach in consideration of the health and wellbeing of all the devotees in our community and congregation', the announcement explained. ${ }^{1}$ Not even a week later, just a few

1 Because my earlier work anonymized the name of the temple and its location, I follow the same practice here. 
days after the event, the temple had cancelled all public events, closed its doors to most visitors, and shifted its religious practices online. It is notable that the temple made these decisions before the US state in which it is located mandated such closures, and before many neighbouring Christian churches did so. This Hare Krishna temple, one whose leaders told me locals still consider to be a cult, embraced public health decisions faster than the mainstream religious organizations surrounding it.

Nine months and many hundreds of thousands of deaths later, another American new religious group took a radically different approach. A storefront neo-Charismatic church - one combining aspects of Pentecostalism, Catholic worship, and other influences - openly flouted statewide public health guidelines and even a legal ban on church services, and opened for a boisterous worship and group meal on the last Sunday of Advent. 'Praying together is essential', the pastor told a newspaper reporter tracing the impact of the pandemic in this mostly Latinx community. Most of the attendees, as well as the pastor, fell ill. Three worshippers died, including a man described as an 'expressive worshipper' who had removed his mask so as to pray more fervently. 'I'm going to be fine', his children recounted him saying, 'The blood of Jesus will cover me' (Fink 2011).

These two cases, separated by time and space, as well as theology and demographics, reveal the problem in generalizing how new religious groups have responded to the COVID-19 pandemic. Both the Advent season and the Gaura Purnima festival represent important moments of social gathering and solidarity in these two religious communities. Leaders in both communities put faith in the divine as they understood it. Yet in one case, the religious community embraced public health science even before it was legally required to do so, whereas in the other, the group rejected those limits. The consequences in the latter case were dire. To understand why these communities operated as they did, one must analyse the different types of new religious movements, their social and religious locations, and how adherents and leaders in the movements understand their relationship to the wider society and its norms.

\section{Social alignment}

Leaders and adherents of new religious movements (NRMs) must carefully navigate their relationship with broader society. While there is neither a formal definition of NRMs, nor a universally accepted set of qualities demonstrated by such groups, they are generally characterized as being deviant within their host societies (Dawson 2006: 72). As such, they occupy socially liminal locations. The scholars of new religions David G. Bromley and J. Gordon Melton recently suggested a categorization of new religious groups based on the degree of social and cultural alignment between religious organizations and established institutions (2012). Building on Benton Johnson's reformulation of church/ sect typology as based on degrees of cultural tension (1963), which itself develops from Ernst Troeltsch's church/sect model (1931), Bromley and Melton (2012) argue that centring an NRM's relation to its host society offers the most useful typology of such movements. Specifically, they look to the degree to which the values and identity of such groups align with broader norms. 'The form and degree of cultural and social alignment ... ultimately forms the basis for their social location', Bromley and Melton explain (2012: 7). If this is so, then understanding how an NRM aligns with social norms has predictive value in understand- 
ing how a movement responds to a novel situation, such as the COVID-19 pandemic.

The Bromley and Melton model offers a typology of four types of alignment and aligned institutions: dominant, sectarian, alternative, and emergent religious groups. Religious movements within the dominant traditions group, even if recently formed, align with each other and broader norms. They constitute the normative religious world, what is often called by NRM researchers the host society. Sectarian groups remain mostly aligned, but challenge some religious, social, or cultural norms. Alternative and emergent religious groups, by contrast, represent competing religious norms and do not align with other religious traditions or social and cultural norms. Most new religious movements fall within these latter categories. Within the Western context, Bromley and Melton place movements such as Scientology, Western Esoteric traditions, ISKCON, and radical Christian nationalist movements within the alternative and emergent categories. A few new religious movements, such as new Marian devotional movements and Jesus People groups, occupy the category of sectarian traditions, since they align with dominant traditions such as Roman Catholicism or Evangelical Protestantism. Notably, such determinations depend entirely on the host society and its religious norms.

Bromley and Melton position their model as assisting in the understanding of the operation of NRMs, that it will 'enhance theorizing about different forms of religious organization as well as connecting theorizing in the sociology of religion to broader theoretical currents in sociology' (2012: 18). The COVID-19 pandemic offers an opportunity to test this model. My initial hypothesis was that in their responses to the pandemic, NRMs that demonstrated weak social alignment (i.e. alternative and emergent ones) were unlikely to support public health measures or mainstream scientific responses to the disease, whereas those more aligned with broader religious norms (i.e. sectarian) would be more likely to follow public health mandates and embrace scientific and medical science.

Yet this hypothesis has proved incorrect. NRMs such as Scientology and ISKCON, while weakly aligned with mainstream Western society, tended to proactively support public health measures, including masking mandates, social distancing requirements, and vaccination efforts. Scientology, for example, not only proactively embraced sound public health guidance, but engaged in extensive volunteer efforts in response to the pandemic (Šoryte 2020). The esotericist Movement for Spiritual Integration into the Absolute (MISA), which is so poorly aligned with its host European societies that its founder lives in exile, both accepted mainstream public health mandates and supplemented them with alternative, esoteric approaches (Introvigne 2020a). Yet other poorly aligned NRMs, such as The Garden, a North American eco-spirituality commune that bills itself as a 'sustainable alternative to the mainstream society' (The Garden 2018) not only rejected mask mandates, but embraced COVID denialism (Asarch 2021). By contrast, several NRMs that seem more aligned with social norms, such as the aforementioned storefront church, tended to follow the pattern of many other (but not all) Evangelicals in rejecting public health efforts. Clearly, social alignment does not explain everything.

This model fails to predict how NRMs responded to the COVID-19 pandemic because it imagines too totalistic a vision of social and cultural norms. While some contemporary and historical societies do 
exhibit relatively monolithic norms, at the present moment most do not. This is especially true in today's West, which is characterized by fragmentation across ideological lines. Particularly the North American context that I initially analysed cannot be said to demonstrate any sort of dominant pole to which NRMs might align. While the competing ideological camps may agree on a shrinking number of shared values, this does not provide a stable footing for the analysis of normative alignment, nor utility for comparing how new religions respond to novel situations.

Yet with some minor adjustment, the alignment model does help explain how and why various NRMs responded to the COVID-19 pandemic. Rather than envision alignment with monolithic social and cultural norms, NRMs strategically align themselves with subcultures, competing ideological nexuses within a single society. Such competing countercultural norms can be understood as frames in keeping with Erving Goffman's (1974) approach of frame analysis. Frames encompass an individual's or group's most salient beliefs, ideologies, and values, and the act of framing organizes experiences and allows individuals to make sense of their lives in light of those beliefs, ideologies, and values.

In his analysis of the rise of the Hare Krishna movement (2018), E. Burke Rochford argued that the movement's early success in the 1960s and 1970s depended on successful alignment of the movement and its ideology with subcultural developments and the worldviews of prospective adherents. Rochford postulates frame alignment as a means of integrating the worldview of participants and movements, defining frame alignment as the linkage of individual and [social movement] interpretive orientations, such that some set of individual interests, values and beliefs and [social movement] activities, goals, and ideology are congruent and complementary' (Snow et al. 1986: 464). The model explains how new religions such as the Hare Krishnas define their relationships to broader culture (the external frame), and how this provides meaning to adherents within the ideologies of the new religious movement (the internal frame).

While Rochford (2018) employs frame alignment as a means of understanding the growth of an NRM in terms of its recruitment strategies, I extend the model here to explain how NRMs have responded to a novel situation, the COVID-19 pandemic. Social responses to the pandemic and the public-health efforts coalesced into competing sets of interests, values, and beliefs, that is, frames. Such frames varied by social location. To return to the two examples that opened this essay, both in the North American context, the two groups aligned themselves with competing frames. One frame, to which the ISKCON temple aligned, emphasizes trust in scientific authorities, public health measures, and collective action to support social wellbeing. A competing frame, to which the storefront church aligned, relies on mistrust of scientific and governmental authorities and an emphasis on notions of individual freedom. New religious movements possess their own frames, ones implicated within broader religious perspectives. I argue here that NRMs responded to the pandemic by aligning their internal frames with one or more external frames. This allowed them to strategically align themselves with specific social and cultural values. This article offers four case studies that occupy different social, geographic, and religious locations to tease out patterns in new religious movement responses to the COVID-19 pandemic. 


\section{Case study \#1: Shincheonji}

The Shincheonji Church of Jesus, based in South Korea, has the distinction of being the first new religious movement explicitly connected to the spread of the COVID19 pandemic. Founded in 1984 by Lee Man-hee, Shincheonji occupies a marginal position in South Korean society. While Christian in origin and aligning with many aspects of Protestant theology, the dominant religious tradition in South Korea, Shincheonji's model of aggressive and at times deceptive proselytizing, and its intensive competition with other Protestant Christian denominations, marks it as outside Korean religious norms (Kim and Bang 2019; Introvigne 2020b). Its embrace of mysticism, apocalypticism, a messianic view of its founder, and an esoteric interpretation of the Christian scriptures also position it as outside Korean Christian theological norms, meaning it aligns weakly overall. David W. Kim and Won-il Bang characterize Shincheonji and similar new Korean Christian movements as operating outside such norms, writing that such 'prophetic and mystical theology in the perspective of globalisation ... often challenges the members of traditional churches' (2019: 5). Kim and Bang indicate that opponents have compared the group to the Islamic State (p. 15), marking Shincheonji's totalistic vision of world transformation as inherently threatening to the social order. The scholar of new religions Massimo Introvigne argues that opposition to Shincheonji may be traced to a more mundane complaint: its rapid growth came at the expense of the more mainstream churches, which responded by demonizing the group and labelling it as a marginal religious movement (2020b: 14).

In February 2020 a middle-aged Shincheonji adherent, identified as Patient 31, tested positive for SARS-CoV-2, the virus that causes COVID-19, after attending Shincheonji religious services in the southeastern city of Daegu. Details vary among both media and academic sources in terms of the diagnosis and whether there had in fact been an earlier misdiagnosis, but there is a consensus that Patient 31 unwittingly spread the disease among fellow worshippers, and then the general public. A month later, approximately two-thirds of South Korea's cases, all clustered in Daegu, were traced to Patient 31 (Weiner et al. 2020: 2-3; Introvigne et al. 2020: 76). Despite cooperating with public health authorities by curtailing worship and assisting in contract-tracing, Shincheonji faced an immediate and prolonged backlash, including ongoing death threats against members, even a year on from the initial case (SangHun 2020b).

The spread of COVID-19 from Patient 31 within the Shincheonji community occurred not only because of the virulence of the SARS-CoV-2 virus, but because of the religious norms and teachings of Shincheonji itself, that is, its frame. Members of the movement promote a culture of devotion and dedication, even taking attendance registers at meetings for worship to track members' piety. Consequently, even adherents feeling ill report that they avoid missing worship services, and attendance is usually quite high. One ex-member explained to investigative journalists,

'The culture was, even though you're sick you come in on Sunday. If you're so sick you can't come Sunday, you have to come on Monday or Tuesday - you have to make up for the time,' Kim says. He describes how, when he was a member, followers would sit on the floor during hours-long services 'packed together like sardines'. (Hancocks and Seo 2020) 


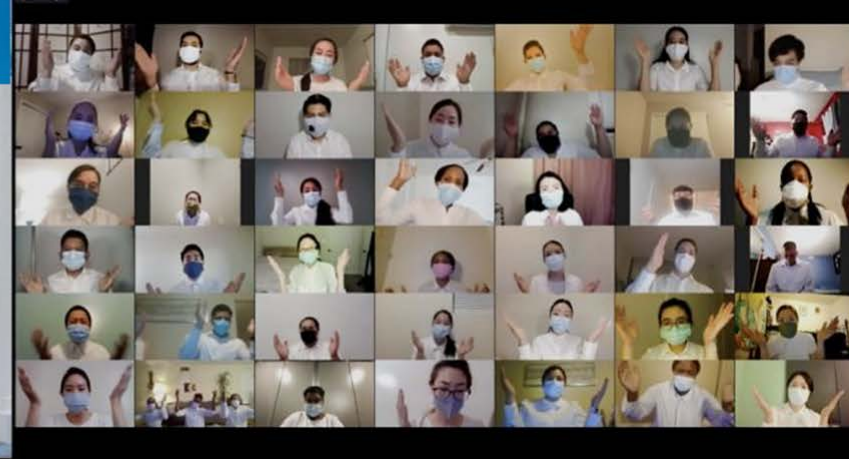

Shincheonji's September 2020 'COVID-19 Overcome Online Prayer Meeting' religious gathering, approximately eight months after the initial cluster event.

Ex-members' accounts must be read with suspicion, and subjective claims such as being 'packed like sardines' reveal as much about anti-Shincheonji media bias as they do actual practices, but the pattern described here, even in its most basic claims, shows why Shincheonji norms were conducive to the spread of the virus. Other members and ex-members familiar with the group indicated that worshippers engage in extensive vocalizations - a common feature of many Korean religions - frequently calling out 'Amen' as a refrain throughout the sermons, which results in expelling viruscontaining respiratory droplets (Kuhn 2020), the main means by which the virus spreads (CDC 2020). In this case, central religious values of the movement (unintentionally) aligned with the biological needs of the virus, leading infected individuals to attend worship in close proximity to others and to expel infected droplets, spreading the contagion.

Shincheonji responded to the emergence of the COVID-19 pandemic with a seeming lack of clarity, at times proactively engaging with public health goals and requirements and at other times shirking them. This represents the general poor alignment of Shincheonji with South Korean society. Rather than forcefully position itself as part of the mainstream, the group assumed an outsider position. Shincheonji's leader Lee Man-hee blamed 'the evil [people] who got jealous of Shincheonji's rapid growth' and deflected blame towards China, rather than accepting that the movement's own religious norms and practices had contributed to a super-spreader event (Sang-Hun 2020a). The movement's leaders also rejected mask mandates, especially during worship, which they regarded as disrespectful to God, based on the movement's teachings of worshipping without any sort of facial impediment (Hancocks and Seo 2000; Sang-Hun 2020c). While the group's religious position against eyeglasses and other facial accessories predated the pandemic, leaders notably did not exempt masks from this ban. The group therefore, led by their internal religious framing, rejected this method, which has been proved to be most effective in preventing spread of SARS-CoV-2 (CDC 2020), and one mandated by South Korean health officials.

Yet Shincheonji did not align itself entirely against public health measures. The movement curtailed worship immediately after the outbreak, seeking to contain the spread of the virus. When asked, the movement's leaders provided the health authorities with a list of the group's entire 
membership to aid in contact tracing. Given the movement's penchant for privacy and secrecy (Grisafi 2021), such willingness was remarkable. Yet the list itself proved controversial. The movement provided multiple contradictory lists, some including foreigners, and domestic students, and some not. Introvigne and his collaborators argue that the discrepancies resulted from simple confusion (Introvigne et al. 2020: 80), a position that the Korean studies scholar John G. Grisafi (2021) notes was also taken by the Vice-Minister of Health Kim Kang-lip. Yet, as Grisafi also notes, other Korean authorities and the wider public accused Shincheonji of malfeasance. Regardless of their intentions, the bungled response to the South Korean health authorities' request for a membership list reinforced the lack of clear alignment between Shincheonji's own frame - which emphasized distinctiveness and a suspicion of outsider authority - and that of public health officials in calling for absolute candour and scientific accuracy.

Further muddling the situation, on 2 March 2020 Lee Man-hee took the unusual step of appearing on national television to issue a formal apology on behalf of the Shincheonji Church of Jesus. Donning a face mask, Lee knelt and bowed twice before the camera and declared that he 'would like to offer my sincere apology to the people on behalf of our members' (Sang-Hun 2020a). He also vowed that the group would cooperate with the health authorities to contain the outbreak (Hyun-ju 2020). Since that time, the Shincheonji movement has sought to align itself more clearly with normative public health measures and medical science, including Lee's encouragement to the faithful who had recovered from COVID19 to donate plasma for scientific research purposes (Cha 2020). Massimo Introvigne and Rosita Šorytė note how the movement's willingness to encourage plasma donations emerge directly from the millennial teachings of the movement and their beliefs that 'acts of charity and kindness ... have cosmic consequences' (2021). Shincheonji's frame alignment, in other words, must be read not only as good public relations, or a survival tactic, but embedded within their own beliefs and values, i.e. their own religious frame. This realignment approach seems to have worked in both directions. Though Lee was initially charged with a violation of reporting laws for failing to provide an accurate and thorough membership list, a judge ruled in his favour in January 2021, seemingly settling the matter (BBC 2021; Introvigne 2021).

The Shincheonji case represents an unusual one, in that the new religious movement was itself entangled within the epidemiology of the disease outbreak. But this made its response all the more salient. The movement's vacillation between rejecting public health requirements (opposing the use of masks, blaming the outbreak on enemies or foreigners) and embracing them (provision of data, the public apology, assistance with scientific research) should not be read as floundering, but rather as a process by which the movement gradually aligned itself with the wider South Korean society. Grisafi argues that the underlying concern was not the pandemic, but the relationship of this NRM to wider social norms, and that their response to the pandemic must be read in this light. 'While the spread of COVID-19 was unquestionably a real concern, it only added to Shincheonji's marginalization and enabled further popularization of pejorative discourse, but did so on the foundation of existing marginalization of the religion', explains Grisafi (2021). Given the experience of the movement's leadership and adherents and their perception of persecution (Kim and Bang 
2019; Introvigne et al. 2020), it is not surprising that they felt their movement to lack frame alignment with South Korean norms regarding the COVID-19 pandemic. Indeed, their religious frame does not align with that of other, normative, South Korean churches. Yet the group deliberately came to align itself with the public health framing of its surrounding society.

\section{Case study \#2: ISKCON}

Shincheonji responded to the COVID-19 pandemic while the group itself served as an unwitting vector of its introduction into Korean society. Other NRMs responded to the pandemic at arm's length, seeking to proactively position themselves rather than respond to the disease already in their midst. The International Society for Krishna Consciousness, already described in the opening vignette of this article, rather explicitly and globally sought to align itself with public health mandates, reputable science, and respect for authority and social norms. They did this not only in societies wherein they operate as alternative or emergent, to use Bromley and Melton's terminology (such as the United States and Europe), but also in India, where the movement presents itself, and is often seen as, aligned with the dominant religious milieu.

The International Society for Krishna Consciousness, known both by its acronym ISKCON, and by its popular moniker 'the Hare Krishna movement', was founded in 1966 by A. C. Bhaktivedanta Swami Prabhupada, an Indian monk who travelled to the United States to promulgate the spiritual teachings of his lineage of Vaishnavism. One of the first wave of countercultural new religious movements of the 1960 s and 1970s, ISKCON embraced a 'turning to the East', as the Christian theologian and scholar Harvey Cox termed it
(1978), combining its adherents' quests for religious authenticity and meaning with the perceived exoticism of Asian religiosity. ISKCON drew most of its adherents from the counterculture, both in the United States where it began, and in the United Kingdom and other international Western locations to which it expanded (Knott 1988: 44-6; Rochford 2007: 13-15).

The movement self-consciously presented itself as an alternative to, and challenging of, Western social norms, aligning itself against mainstream Western culture. Prabhupada spoke out against what he regarded as the corruption, declension, and secularization of the present age, and called for spiritual renewal through Krishna Consciousness. The movement in its early days came to assume oppositional approaches to many social institutions, such as the government and the educational establishment. The movement initially aligned itself with political protest and countercultural spiritual seekers (Rochford 2018: 50).

The Hare Krishna movement held a particularly negative view of Western science, envisioning it as hopelessly mired in materialist (i.e. empiricist) assumptions, entangled with industry and destructive technology, and fundamentally amoral if not immoral (Zeller 2010a, 2010b). In his analysis of the movement's approach to science, the scholar of new religious movements, the current author, explains that ISKCON 'offered an alternative scientific method, one that rejected empiricism and instead emphasized study of the revealed truths of its own texts. Such an approach to science so obviously differed from mainstream Western science that it entailed replacing the latter with a new, Krishnacentred, science' (2010a: 259). ISKCON's approach to science therefore amplified its general misalignment with certain core 
social, cultural, and religious frames of the West. Adherents' rejection of Western science and embracing of a Krishna-centred alternative represented a fundamental challenge to Western norms.

Since the death of its founder and charismatic leader the Hare Krishna movement has undergone a radical transformation, with its leaders seeking to shed many of its countercultural elements and embrace an identity as a 'Hindu denomination', thereby claiming a legitimate - albeit outsider status in the West, and a more mainstream position in India (Rochford 1985: 271). Rochford identifies this process as world accommodation, or 'a growing alignment with mainstream institutions and cultural conventions' (2007: 205). Part of this process has involved a strategic frame realignment, moving to accept important aspects of Western and global cultural norms, such as conventional family structures and congregational living. Devotees have 'opened themselves to dialogue with, and influence from, the academic, social, legal, and other mainstream institutions of greater society', explain Edwin F. Bryant and Maria L. Ekstrand (2004: 6). The movement has also enacted an armistice in its war with Western science, proactively taking a more positive approach to the scientific mainstream, even while admitting that major ideological disagreements still exist (Aechtner and Zambon, forthcoming). Given this realignment to the social and cultural frames of its host societies, the COVID-19 pandemic has allowed the movement to demonstrate a very specific form of realignment in keeping with recent shifts in the movement towards the mainstream and social norms.

ISKCON maintains its spiritual and organizational centre in Mayapur, India, which is believed to be the birthplace of Chaitanya Mahaprabhu, the fifteenthcentury reformer worshipped by Hare Krishnas as an appearance of God. The movement operates several temples, shrines, shops, guesthouses, and other

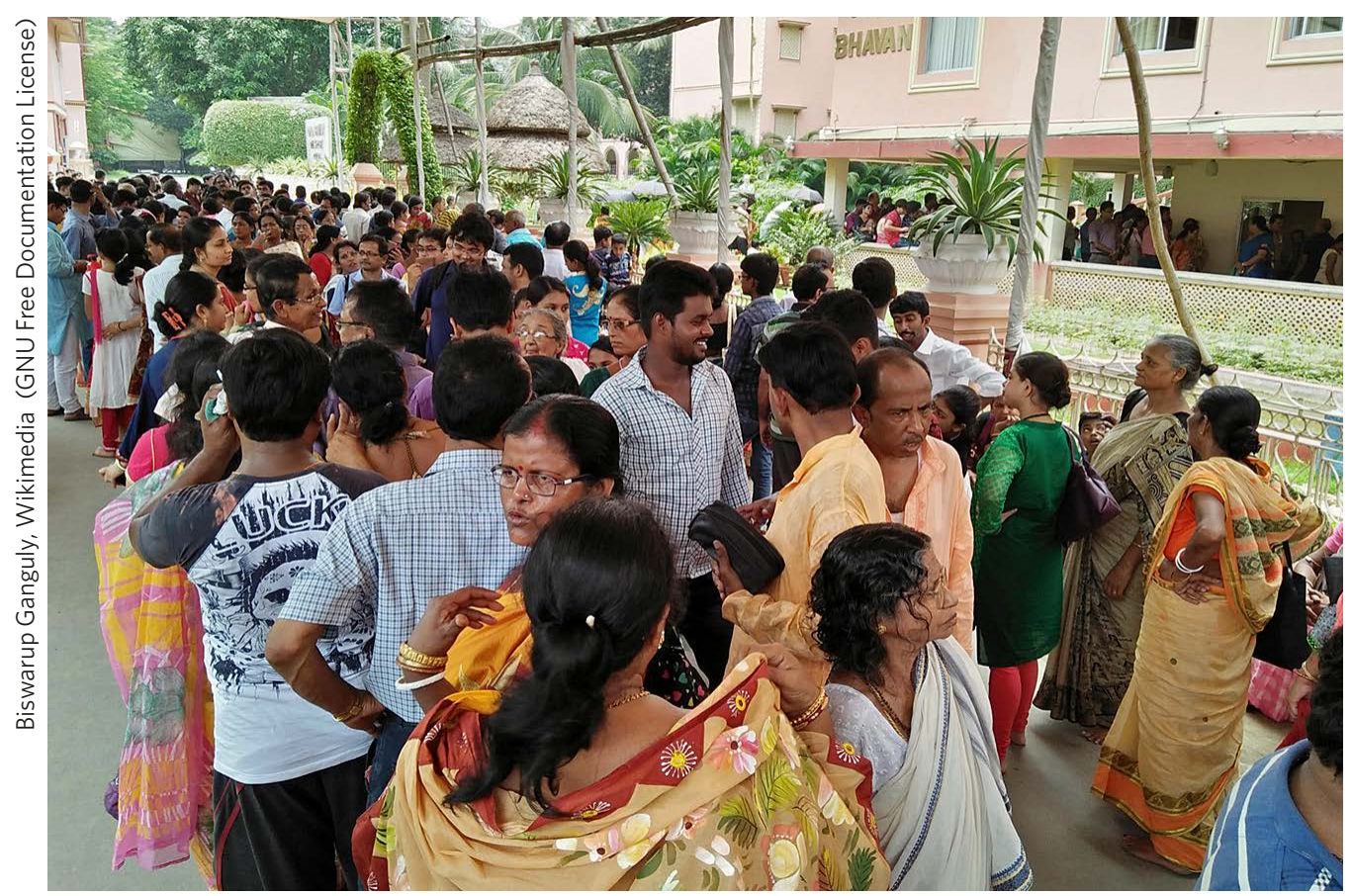

A typical pre-pandemic queue to receive prasad (spiritually elevated food) at ISKCON Mayapur. 
facilities in Mayapur, as well as its organizational headquarters and seat of its Governing Board Commission (GBC). While local ISKCON branches generally maintain autonomy in their operating procedures and decision-making, local leaders look to Mayapur as a model for the movement, and follow the guidance of the GBC.

Tellingly, ISKCON Mayapur took a proactive approach to the COVID-19 pandemic, strongly aligning with public health measures and mainstream scientific approaches to fighting the spread of the disease. In a 19 March 2020 statement, 'Advisory on Corona Virus from ISKCON Mayapur', the movement laid out numerous restrictions on the many pilgrims arriving to Mayapur. The movement restricted access to the main temple to specific times and routes, thermally scanned all arriving pilgrims, erected barricades to separate visitors from the permanent ISKCON residents who work and live there, and cancelled future reservations at its guesthouse. The movement also asked local devotees to refrain from visiting the temple when pilgrims were permitted to visit, effectively creating a quarantine between pilgrims and locals. 'Mayapur management recognises the importance of keeping the community safe and our duty to bring Mahaprabhu's mercy to those visitors who are seeking darshan [viewings] of our most merciful deities', the announcement concluded (ISKCON Mayapur 2020a).

As regional and national Indian public health authorities extended lockdowns in attempts to mitigate the spread of the virus, ISKCON Mayapur followed in close lockstep, demonstrating a clear alignment with social and medical norms. In a tersely worded statement on 25 March 2020, the temple management declared, 'This is to inform that following the government advisory rules on COVID-19, ISKCON Sri Mayapur Chandrodaya Mandir is closed for both devotees and pilgrims till 27 th March as of now' (ISKCON Mayapur 2020b). The same day, the management posted a second statement, closing its four other temples and shrines as of $4 \mathrm{pm}$ 'in line with the restrictions imposed by the government regarding West Bengal lock down' (ISKCON Mayapur 2020c).

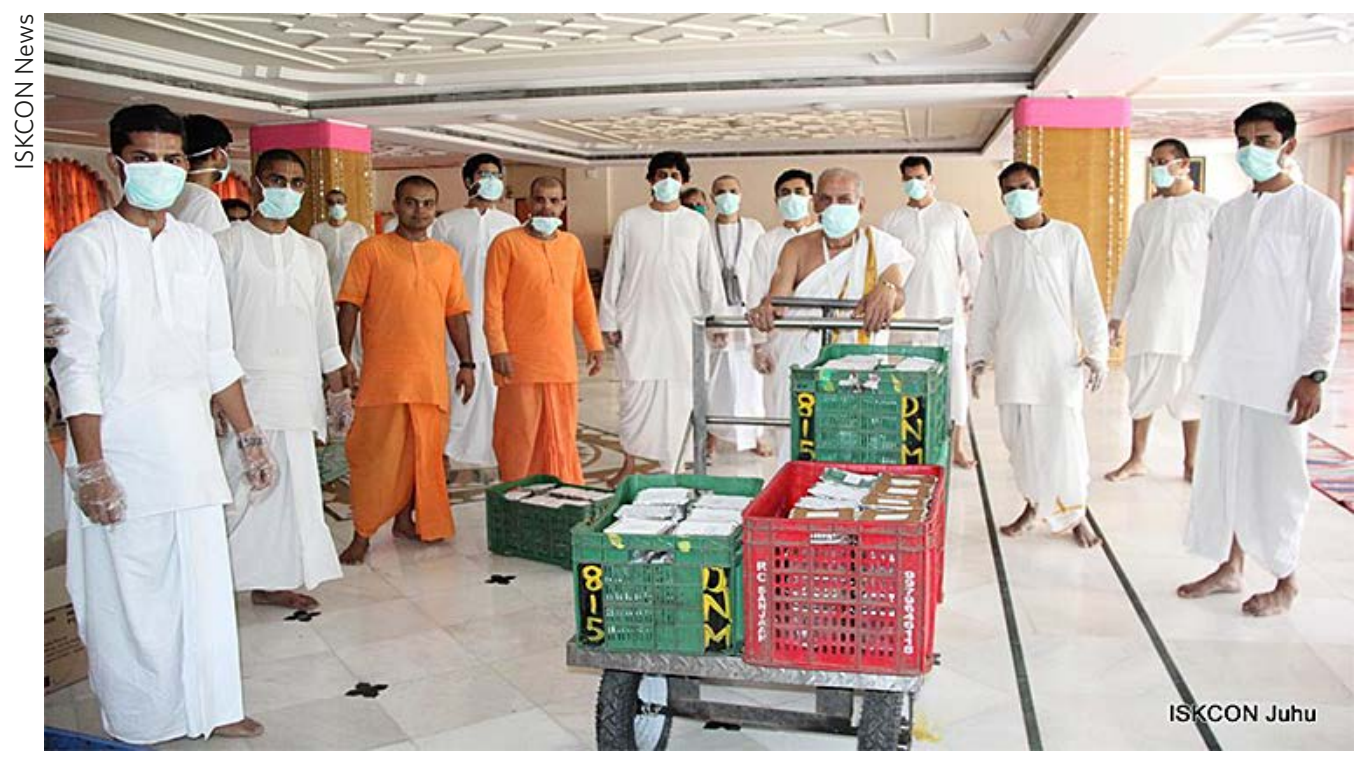

Masked ISKCON members prepare to distribute prasad, April 2020. 
It is hard to overestimate the power of ISKCON's religious and administrative centre explicitly aligning its framing of the pandemic with that of the local and national governmental and health authorities. ISKCON did not blame the pandemic on evil outsiders, divine retribution, or conspiratorial agents. The movement's leaders and adherents treated COVID19 as a public-health problem, just as the mainstream authorities in India did. This provided impetus for Hare Krishnas worldwide to follow suit. ISKCON communities in Belgium, Sweden, Germany, Australia, the United States, and Canada all moved to adopt local health requirements, aligning themselves with their specific social locations.

Whereas Shincheonji occupied a liminal social location, and found itself forced through the advent of the pandemic to creatively realign itself with Korean society, ISKCON had already undergone a shift in frame alignment over the preceding decades. While initially tied to a transnational Western counterculture, the movement's engagement with normative social institutions demonstrated a desire by its leaders and adherents to align their values with those of surrounding society. The movement's efforts to closely follow the public-health guidance of local authorities reflect the way that the Hare Krishna movement sought to embrace normative societal frames.

\section{Case study \#3: The Garden}

In January 2021 a little-known eco-spirituality commune in rural Tennessee, USA, called The Garden, erupted into public consciousness via a series of short videos, memes, and posts made to social media sites such as TikTok and Facebook. The TikTok videos went viral, attracting tens of thousands of viewers. In the videos, a
British traveller who had recently joined the commune described the various activities and philosophies of The Garden, providing a virtual tour and inviting new adherents to join (TreeIsAlive 2021). Some of the movement's practices, particularly one member's decision to fashion clothing out of a deceased cat (Gumson 2021a), struck outsiders as deviant, amplifying the viral spread of the videos. Online debates erupted over whether the commune was a 'cult', and the group itself quickly closed itself to visitors and ceased much of its outreach (Colombo 2021). But during the few months in which The Garden and its members became internet celebrities it demonstrated a curious blend of left-wing politics, 'deep green' religiosity, and (perhaps most surprisingly) COVID denialism.

The Garden aligns most closely with a particular social frame defined by environmentalism, sustainability, and ecological consciousness. Many of the group's practices align with what Bron Taylor calls 'deep green religion', also identified as deep ecology and eco-spirituality (2009). While not the dominant frame of Western society, this frame does not fall entirely outside social or cultural norms. The commune itself emerged from its founder Patrick Martion's participation in the Rainbow Gathering subculture, a quasi-religious movement emphasizing radical individualism, anticonsumerism, and counter-cultural spirituality (Niman 1997). 'The Garden, formerly known as Shut Up and Grow It, is an egalitarian, alternative, leaderless (leaderful), community, propagating a culture of sharing, freedom, and cooperation' (The Garden 2021). The group self-presents an anti-authoritarian and contrarian image, emphasizing opposition to capitalism, modernity, and technology, and embracing radical egalitarianism, communalism, and what the group calls a 'tribal social setting' 


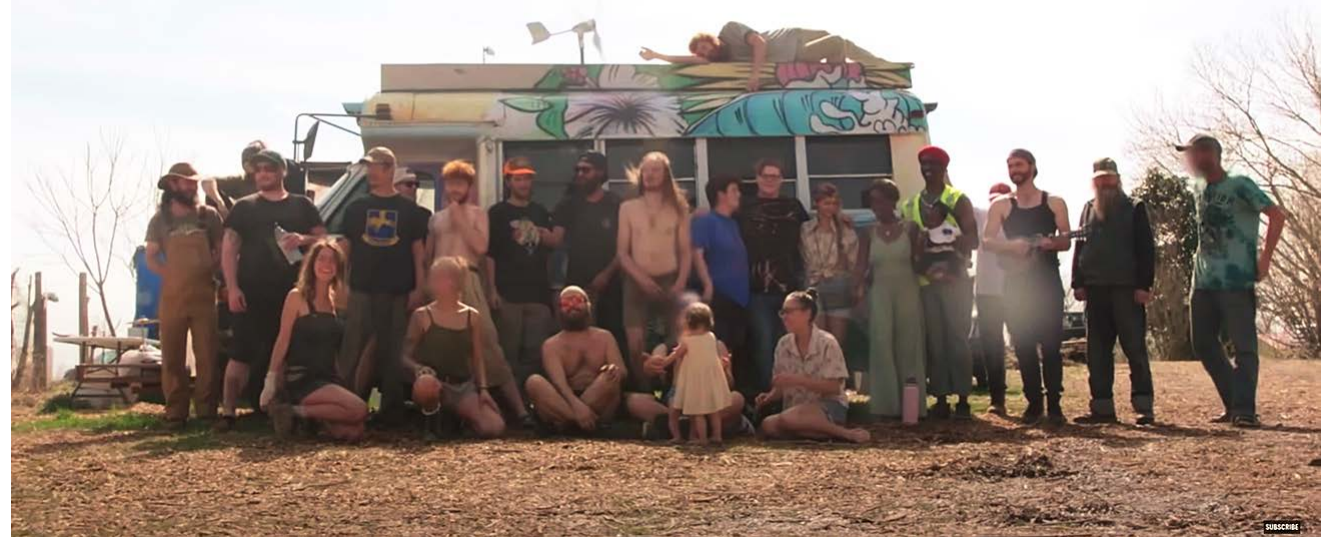

Members of The Garden. Undated photo.

(The Garden 2021). The movement adopts a frame aligned with contemporary ecological counter-culturalism and is reflective of other similarly minded NRMs that reject the frames of neoliberal capitalistic modernity.

This weak alignment with social norms resulted in the movement rejecting the primary normative social frames regarding the COVID-19 pandemic and in The Garden's members embracing a competing frame. Members came to frame the pandemic as manufactured, and public-health measures as at best ineffective, at worst dangerous. This sort of oppositional framing of the COVID-19 pandemic has been most evident among Evangelical Christians (Dias and Graham 2021; Dwoskin 2021), who represent up to a quarter of the population in The Garden's host society of the United States, and operates as a powerful alternative, totalistic frame. While few aspects of The Garden cause it to align with the religious frames of Evangelical Christians and in fact, The Garden aligns very poorly with that subculture - Evangelical framing of the pandemic provided a crossover ideology that members of The Garden embraced. Rel Gumson, one of the group's unofficial spokespeople, posted a series of COVID denial memes to her social media account, attacking masks as 'mind control devices' and the SARS-CoV-2 virus as 'engineered' (2021b). The movement's TikTok videos generally avoided direct mention of the movement's COVID denialism, but projected it implicitly but overtly by the lack of masking, social distancing, or quarantine requirements for visitors and new recruits (TreeIsAlive 2021).

The investigative journalist Mic Wright argued that the movement and its critics engage in a cycle of 'internet trolling, that is to say provocation, against each other. Critics accused the group of being a cult, and members responded by posting a satirical video featuring members drinking Kool-Aid, a reference to the oftcited Flavor-Aid made infamous by the Jonestown murder-suicides and the 'drinking the Kool-Aid' popular culture memetic response it engendered (Feltmate 2018: 116; Crockford 2018: 106-9). Scholars of new religious movements call this pattern 
deviance amplification, and it generally results in NRMs assuming even higher states of tension with their surrounding societies. Wright found that this pattern occurred at The Garden, with one informant telling him that initially the group members 'were not taking the Covid-19 pandemic seriously enough', but that this progressed to outright 'Covid denial', and eventually this member being 'run off' because he disagreed with their stance on the pandemic (Wright 2021). While one must assume a cautious approach to all apostate accounts, Wright confirmed the general contours of this account through internet chat logs. In the case of The Garden, deviance amplification led the movement to increasingly align itself with a frame with which it had little natural affinity, that of COVID denialism and rejection of public-health mandates.

\section{Case study \#4: QAnon}

No new religious movement has attracted as much attention during the pandemic as the political-social-religious movement known as QAnon. Identifying QAnon as an NRM is somewhat contentious, since the movement's avowed aim was, and is, support for former United States President Donald Trump. Yet messianism and millennialism appear just under the surface of this apparently political goal, as well as a conspiratorial demonology that associates its enemies with literal devil-worship (Beverley 2020). The new religious movement scholar Erin Prophet has penned a public essay identifying the place of charisma and prophecy at the heart of QAnon (2020), and the communication studies scholar Jayson Dibble (2021) has done the same, explicitly extending Leon Festinger et al.'s model (1956) of failed prophecies and cognitive dissonance to QAnon. As a recently emergent social movement, journalists rather than scholars have been quicker to lead the assessment of the group, but their perspective supports that of Prophet and Dibble. In the best and most extensive treatment of the group Caroline Mimbs Nyce provides a succinct assessment:

In QAnon, we are witnessing the birth of a new religion. Among the people of QAnon, faith remains absolute. True believers describe a feeling of rebirth, an irreversible arousal to existential knowledge. They are certain that a Great Awakening is coming. They'll wait as long as they must for deliverance. (Nyce 2020)

The manner in which QAnon came to embrace COVID denialism, with its adherents aligning themselves with a frame suspicious of public health and mainstream science, demonstrates the manner in which frame alignment helps explain how and why new religious movements responded to the COVID-19 pandemic. On the surface, initial QAnon ideology says little about the pandemic itself, or the science behind public-health measures, or vaccination. QAnon emerged as a social movement in 2017 on internet discussion forums, its ideology revolving around the messianic role of Donald Trump and a coming 'Storm' in which Trump would lead a global overthrow of a shadowy group of elites that the movement accuses of paedophilia, devil-worship, and child abuse. Based on the anonymous postings of a supposed government turncoat called 'Q', the ideology grew to encompass a vast array of conspiracy theories, subsuming them into a Manichaean worldview of messianic and righteous Trump versus a devil-worshipping cabal of liberal politicians, Hollywood moguls, 'deep state' bureaucrat, international bankers, and other supposed enemies of Trumpism. QAnon is an evolution of the 
same antisemitic and nativist tropes that have long characterized the American religious and political right.

Although ' $Q$ ' themselves did not raise questions about the nature of the pandemic or public-health responses, the QAnon movement quickly aligned itself with the same Evangelical frame that not only rejects public-health measures such as social distancing, masking, and vaccination, but comes to envision these approaches as at best violations of religious civil liberties and at worst actually evil and implicated in the millennial expectations of prophetically oriented Christians. Reading mask mandates as the Book of Revelation's 'Mark of the Beast' and vaccines as part of a millennial timetable for the End Times (Dwoskin 2021), such Evangelical Christians clearly developed a powerful alternative framing of the pandemic and responses to it.
QAnon adherents align themselves and their movement with this Evangelical counter-frame that envisions the pandemic as manufactured and public-health responses as evil. This intense alliance between QAnon and covid denialism', in the words of the investigative journalists Craig Timberg and Elizabeth Dwoskin (2021), has resulted in QAnon adherents labelling public-health efforts like masking and vaccination as murder, war crimes, and violations of fundamental freedoms, and the pandemic itself as either a hoax, or the creation of the anti-Trump cabal. While QAnon believers have not tended to invoke the explicitly Christian language of Revelation and its Evangelical interpreters, the same framing is present. QAnon has effectively duplicated within itself the Manichaean and millennial outlook of the Evangelical frame through this alignment.

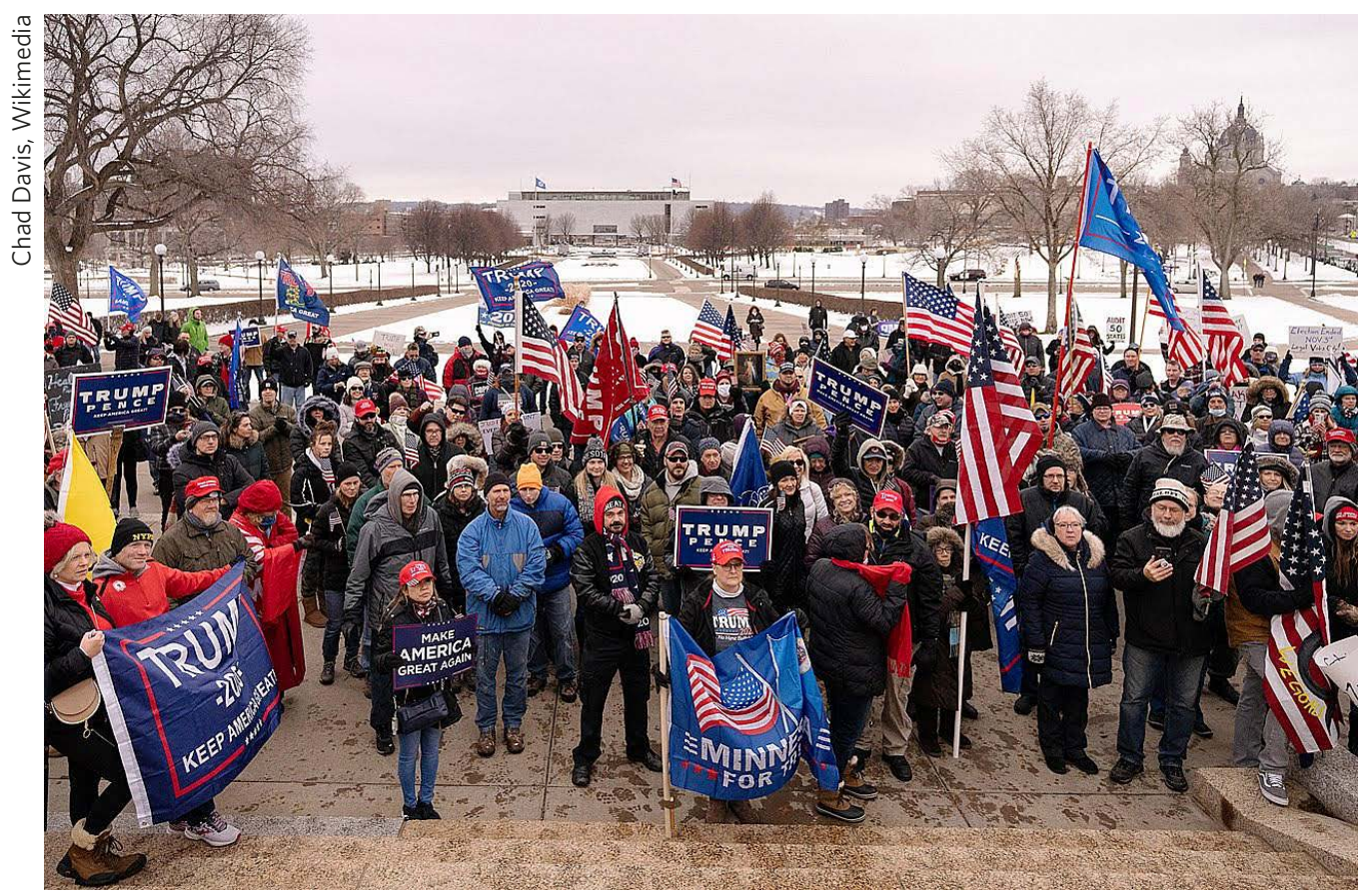

Unmasked QAnon proponents at a November 2020 Minnesota rally. Photographer Chad Davis describes his photo: 'On a day that saw Minnesota break a record high of 8,703 COVID cases, far-right conspiracy theorists Qanon and "Stop The Steal" followers stood maskless shoulder to shoulder outside the Minnesota State Capitol. Speakers led the crowd in bizarre covid/election chants.' 
As a scholar of the New Age movement, Susannah Crockford has argued (2021b) that 'cross-pollination' between apparently disparate religious-social worldviews, what I call frames, is far more prevalent than one might expect. New Age adherents embrace similar forms of conspiracism, providing one way in which QAnon reached into parallel religious-social movements. Dubbed 'conspirituality', religious engagements with the sort of conspiracy theories that define QAnon link it to New Age movements, Evangelical millennialism, and wellness communities (ibid.). In the case of the COVID-19 pandemic, ideological alignment has led New Age practitioners to embrace tenets of QAnon and Evangelical millennialism and come to believe the pandemic itself a hoax and the vaccine indicative of dark plots involving microchips, global elites, and devil-worshipping perverts (Crockford 2021a), effectively a secularized retelling of the claims of some Evangelicals involving the Mark of the Beast, the Antichrist, and other elements of millennialist prophetic traditions. As QAnon has extended beyond the United States it has aligned itself with other alternative frames, such as the Japanese wing of the movement ('JAnon'), which has followed suit with conservative critics of Japanese culture and politics, and conspiratorial claims about the Fukushima nuclear disaster and the Japanese royal family (Zimmerman 2020).

In their assessment of recent research into the sociology of vaccine denial Sophie Mylan and Charlotte Hardman point to the need to consider the scholarship of new religious movements to understand broader forms of vaccine denial. 'Resonance between discourse about NRMs - particularly when labeled as "cults" - and public discourse about the anti-vaccine movement, especially in terms of how a perception of martyrdom may lead to radicalization' (Mylan and Hardman 2021: 1181). This resonance, expressed through a self-perception of outsider status, accurately describes the process by which QAnon adherents came to embrace COVID denialism. Aligning themselves and their social frame with that of Evangelical Christians, who shared similar political sentiments as well as broad cultural identities and perceptions, enabled the overt and explicit alignment of QAnon's framing of the COVID-19 pandemic with that of the most competing prominent frame - COVID denialism and conspiratorialism - rather than accepting the normative scientific and public health framing of the disease and its spread.

\section{Conclusions}

Having considered four new religious movements spanning the globe from South Korea to India to the United States and beyond, it is tempting to develop a typology in line with the Bromley and Melton model to explain and predict how NRMs respond to novel situations such as the COVID19 pandemic. Yet I think this would be folly. The alignment strategies of the four case studies considered here must be read within the specific contexts of the new religious movements themselves and their host communities. The two other published academic studies of new religious movement responses to the COVID-19 pandemic - Introvigne's (2020a) assessment of the Movement for Spiritual Integration into the Absolute (MISA) and Šorytë's (2020) study of Scientology - similarly show that the groups responded in highly idiosyncratic fashions based on their existing religious and social ideologies. One can ascertain patterns, but no single theoretical model can explain how and why the groups responded as they did. Nevertheless, several clear patterns do exist. 
First, groups tended to extend existing alignment patterns rather than break entirely new ground. ISKCON had already engaged in a process of frame (re)alignment, intentionally realigning itself to normative social frames for the past several decades. In aligning with mainstream responses to the pandemic this reinforced a long process of frame alignment. QAnon similarly built upon existing sympathies and parallels with both Evangelicalism and conspirituality to align itself with those subcultures' COVID-denial frames. The Garden adopted a similar framing based on conspiratorial thinking and its own position as poorly aligned with the normative frames of contemporary neoliberal capitalism. Yet Shincheonji, which already suffered from weak frame alignment with South Korean society, demonstrated an active shift in frame alignment strategies in its response to the pandemic. Shincheonji breaks the pattern, but since the movement itself contributed to the outbreak and it faced extensive criticism and threats within its host society, its leaders took the unusual step of an abrupt and intentional realignment. Introvigne and Šoryte found the same in MISA and Scientology.

This leads to the second pattern. The structure of the groups matters. ISKCON and Shincheonji both operate as hierarchal movements. The decisions made by the elite leaders in Mayapur were replicated elsewhere by Hare Krishnas, and Shincheonji's founder Lee Man-hee set directives to reshape the movement's frame alignment strategy. The Garden and QAnon function acephalously. Whereas the other two movements followed the lead of those who made decisions based on what they thought was the best direction for the movements, adherents of QAnon and members of The Garden acted according to their own values and beliefs, propelling the movements in directions that did not align with broader society. Rather than follow a strategic vision, they followed existing sympathies and congruences.

Finally, the movements' ideologies contributed to their alignment strategies. While all four case studies possessed religious ideologies that put them in a somewhat tense relationship with their host environments, both ISKCON and the Shincheonji Church of Jesus call for engagement with broader society to improve it and serve the common good. ISKCON does so in hopes of recreating what they regard as an ideal Vedic society, while Shincheonji sees its mission as being part of a millennial goal to model the Christly Kingdom on Earth. Both movements' theologies incentivize them to engage with their host societies, which in turn encourages alignment with the norms and therefore frames of those societies. By contrast, The Garden exists in a sectarian and separatist form. Like the Amish and other radical reformers before them, members of The Garden had little incentive to engage with a society from which they had turned away. This provided no impetus for frame alignment. QAnon, while nominally aligned with the then-president of one of the world's most powerful nations, selfconsciously presented itself as antagonistic towards the individuals and institutions that define the norms of Western society. This mantle of deviance, like that of The Garden, led participants toward alignment with a deviant framing regarding the COVID-19 pandemic.

While one cannot offer a totalistic theory of how and why NRMs responded to the pandemic in the way they did, this article has suggested that close attention to the contexts, structure, and ideologies of new religious movements does reveal and explain how such groups positioned, or aligned, themselves in relation to broader 
frames, i.e. cultural and social values, beliefs, and norms. Building on Goffman (1974), Rochford (2018), and Bromley and Melton's models, this article suggests that frame analysis can be deployed not only to explain conversion and social movement emergence, but how NRMs respond to novel situations within the context of fragmented societies. While this article used four case studies and the specific instance of the COVID-19 pandemic, the overall argument and method are useful for analysis of other groups and unexpected novel situations that may arise in the future.

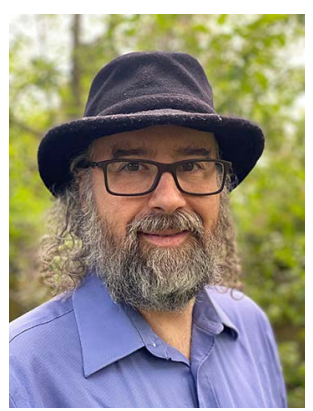

Benjamin E. Zeller is Associate Professor and Chair of Religion at Lake Forest College (Chicago, USA). He researches religious currents that are new or alternative, including new religions, the religious engagement with science, and the quasi-religious relationship people have with food. He is author of Heaven's Gate: America's UFO Religion (NYU Press 2014), Prophets and Protons: New Religious Movements and Science in Late Twentieth-Century America (NYU Press 2010), editor of Handbook of UFO Religions (Brill 2021), and co-editor of Religion, Food, and Eating in North America (Columbia University Press 2014) and The Bloomsbury Companion to New Religious Movements (Bloomsbury 2014). He also designed the Sacred Chicago project, a digitalization project involving Chicago's sacred spaces. He holds a Ph.D. from the University of North Carolina and an M.T.S. from Harvard University. He is co-general editor of Nova Religio: The Journal of Alternative and Emergent Religions.

\section{Bibliography}

Aechtner, Thomas, and Oliver Zambon. Forthcoming. 'The Bhaktivedanta Institute, ISKCON, and evolving religion-science perspectives', Nova Religio: The Journal of Alternative and Emergent Religions.

Asarch, Steven. 2021. 'A free-living commune in Tennessee used TikTok to attract new members, but the strategy may have backfired', Insider, 19.3.2021, <https://www.insider. $\mathrm{com} /$ commune-tennessee-tiktok-the-garden-2021-3>.

BBC. 2021. 'Shincheonji: Korean sect leader found not guilty of breaking virus law', BBC, 13.1.2021, <https://www.bbc.com/news/ world-asia-55642653>.

Beverley, James A. 2020. The QAnon Deception: Everything You Need to Know about the World's Most Dangerous Conspiracy Theory (Concord: EqualTime).

Bromley, David G., and J. Gordon Melton. 2012. 'Reconceptualizing types of religious organization: dominant, sectarian, alternative, and emergent tradition groups', Nova Religio: The Journal of Alternative and Emergent Religions 15(3): 4-28, doi: <https://doi. org/10.1525/nr.2012.15.3.4>.

Bryant, Edwin F., and Maria L. Ekstrand (eds.). 2004. The Hare Krishna Movement: The Postcharismatic Fate of a Religious Transplant (New York: Columbia University Press).

CDC. 2020. 'Science brief: SARS-CoV-2 and potential airborne transmission', Centers for Disease Control and Prevention, <https:// www.cdc.gov/coronavirus/2019-ncov/science/science-briefs/scientific-brief-sarscov-2.html> (accessed 11.4.2021).

Cha, Sangmi. 2020. 'South Korea church hit by COVID-19 says members to give plasma for research', Reuters, 23.6.2020, <https://www. reuters.com/article/us-health-coronavirussouthkorea/south-korea-church-hit-bycovid-19-says-members-to-give-plasmafor-research-idUSKBN $23 \mathrm{U}_{1} \mathrm{QA}>$.

Colombo, Charlotte. 2021. 'What is The Garden? Exploring TikTok's first-ever "commune"', Dexerto.com, 20.3.2021, <https:// www.dexerto.com/entertainment/what-isthe-garden-exploring-tiktoks-first-evercommune-1537366/> (accessed 11.4.2021).

Cox, Harvey, 1978. Turning East: Why Americans Look to the Orient for Spirituality - and 
What That Search Can Mean to the West (New York: Simon and Schuster).

Crockford, Susannah. 2018. 'How do you know when you're in a cult? The continuing influence of Peoples Temple and Jonestown in contemporary minority religions and popular culture, Nova Religio: The Journal of Alternative and Emergent Religions 22(2): 93-114, doi: <https://doi.org/10.1525/ nr.2018.22.2.93>.

- - . 2021a. "How "positivity" can lead to conspiratorial thinking', Religion Dispatches, 4.1.2021, <https://religiondispatches.org/ how-positivity-can-lead-to-conspiratorialthinking/>.

- - . 2021b. 'Q Shaman's new age-radical right blend hints at the blurring of seemingly disparate categories', Religion Dispatches, 11.1.2021, <https://religiondispatches. org/q-shamans-new-age-radical-rightblend-hints-at-the-blurring-of-seeminglydisparate-categories/>.

Dawson, Lorne L. 2006. Comprehending Cults: The Sociology of New Religious Movements (Oxford University Press).

Dias, Elizabeth, and Ruth Graham. 2021. 'White Evangelical resistance is obstacle in vaccination effort', The New York Times, 5.4.2021, $<$ https://www.nytimes.com/2021/04/05/us/ covid-vaccine-evangelicals.html $>$.

Dibble, Jayson. 2021. 'Does ridiculing Q followers fuel the fire? Historical lessons in applied social science, History News Network, 7.3.2021, <https://historynewsnetwork.org/article/179428>.

Dwoskin, Elizabeth. 2021. 'On social media, vaccine misinformation mixes with extreme faith, The Washington Post, 16.2.2021, $<$ https://www.washingtonpost.com/technology/2021/02/16/covid-vaccine-misinformation-evangelical-mark-beast/>.

Feltmate, David. 2018. 'Peoples Temple: a lost legacy for the current moment', Nova Religio: The Journal of Alternative and Emergent Religions 22(2): 115-36, doi: <https://doi. org/10.1525/nr.2018.22.2.115>.

Festinger, Leon, Henry W. Riecken, and Stanley Schachter. 1956. When Prophecy Fails: A Social and Psychological Study of a Modern Group (Minneapolis: University of Minnesota Press).

Fink, Sheri. 2011. 'Dying of Covid in a "separate and unequal" L.A. hospital', New York
Times, Section A1: 1, 8.2.2011, <https:// www.nytimes.com/2021/02/08/us/covidlos-angeles.html>.

Goffman, Erving. 1974. Frame Analysis: An Essay on the Organization of Experience (Cambridge: Harvard University Press).

Grisafi, John G. 2021. 'A marginal religion and COVID-19 in South Korea: Shincheonji, public discourse, and the shaping of religion', Nova Religio: The Journal of Alternative and Emergent Religions 25(1): 40-63, doi: $<$ https://doi.org/10.1525/nr.2021.25.1.40>.

Gumson, Rel. 2021a. <https://www.tiktok.com/@rocknrelmusic> (accessed 11.4.2021).

- - . 2021b. Facebook homepage, <https:// www.facebook.com/rel.gumson> (accessed 11.4.2021).

Hancocks, Paula, and Yoonjung Seo. 2020. 'How novel coronavirus spread through the Shincheonji religious group in South Korea, CNN, 26.2.2020, <https://www.cnn. com/2020/02/26/asia/shincheonji-southkorea-hnk-intl/index.html>.

Hyun-ju, Ock. 2020. 'Shincheonji head apologizes, vows full support', The Korea Herald, 2.3.2020, <http://www.koreaherald.com/ view.php?ud=20200302000816>.

Introvigne, Massimo. 2020a. 'Esotericism in the mirror of COVID-19: Gregorian Bivolaru, MISA, and the pandemic', The Journal of CESNUR 4(5): 42-63, doi: <https://doi. org/10.26338/tjoc.2020.4.5.3>.

- - . 2020b. 'Shincheonji: an introduction', The Journal of CESNUR 4(3): 3-20, doi: $<$ https://doi.org/10.26338/tjoc.2020.4.3.1>.

- - . 2021. 'Shincheonji's chairman Lee not guilty of breaking virus law: the decision', Bitter Winter, 25.1.2021, <https://bitterwinter.org/shincheonjis-chairman-lee-notguilty-of-breaking-virus-law/> (accessed 24.5.2021).

Introvigne, Massimo, Willy Fautré, Rosita Šorytė, Alessandro Amicarelli, and Marco Respinti. 2020. 'Shincheonji and the COVID-19 epidemic: sorting fact from fiction', The Journal of CESNUR 4(3): 70-86, doi: <https://doi. org/10.26338/tjoc.2020.4.3.5>.

Introvigne, Massimo, and Rosita Šorytè. 2021. 'Saving lives by donating plasma: why are Shincheonji's good deeds ignored?' CESNUR Library, <https://www.cesnur. org/2020/shincheonji-plasma.htm> (accessed 11.4.2021). 
ISKCON Mayapur. 2020a. 'Advisory on Corona virus from ISKCON Mayapur', ISKCON Mayapur, 19.3.2020, <https://www. mayapur.com/2020/advisory-on-coronavirus-from-iskcon-mayapur/> (accessed 11.4.2021).

_-_. 2020b. 'Online puja offerings are limited, ISKCON Mayapur, 25.3.2020, $<$ https://www.mayapur.com/2020/ online-puja-offerings-are-limited/> (accessed 11.4.2021).

- - 2020c. 'Advisory on government restrictions due to Corona virus', ISKCON Mayapur, 25.3.2020, <https://www. mayapur.com/2020/advisory-on-government-restrictions-due-to-corona-virus/> (accessed 11.4.2021).

Johnson, Benton. 1963. 'On church and sect', American Sociological Review 28(4): 53949, doi: <https://doi.org/10.2307/2090070>.

Kim, David G., and Won-il Bang. 2019. 'Guwonpa, WMSCOG, and Shincheonji: three dynamic grassroots groups in contemporary Korean Christian NRM history', Religions 10 (3): 212, doi: <https://doi. org/10.3390/rel10030212>.

Knott, Kim. 1988. My Sweet Lord: The Hare Krishna Movement (San Bernadino: R. Reginald Borgo Press).

Kuhn, Anthony. 2020. 'Secretive church sect at the center of South Korea's coronavirus outbreak, NPR (National Public Radio), 24.2.2020, <https://www.npr.org/sections/ goatsandsoda/2020/02/24/808914718/ secretive-church-sect-at-the-center-ofsouth-koreas-coronavirus-outbreak $>$.

Mylan, Sophie, and Charlotte Hardman. 2021. 'COVID-19, cults, and the antivax movement', The Lancett 397(10280): 1181, doi: <https://doi.org/10.1016/ So140-6736(21)00443-8>.

Niman, Michael I. 1997. People of the Rainbow: Nomadic Utopia (Knoxville: University of Tennessee Press).

Nyce, Caroline Mimbs. 2020. 'QAnon is a new American religion', The Atlantic, 14.5.2020, $<$ https://www.theatlantic.com/newsletters/ archive/2020/05/qanon-q-pro-trump-conspiracy/611722/> (accessed 11.4.2020).

Prophet, Erin. 2020. 'Fulfillment of prophecy? Yes, some Evangelicals really do believe Trump is the "chosen one", Salon, 18.10.2020, <https://www.salon. com/2020/10/18/fulfillment-of-prophecyyes-some-evangelicals-really-do-believetrump-is-the-chosen-one/ $>$.

Rochford, E. Burke. 1985. Hare Krishna in America (New Brunswick: Rutgers University Press).

- - . 2007. Hare Krishna Transformed (New York: New York University Press).

- - . 2018. 'Aligning Hare Krishna political activists, hippies, and Hindus', Nova Religio: The Journal of Alternative and Emergent Religions 22(1): 34-58, doi: <https://doi. org/10.1525/nr.2018.22.1.34>.

Sang-Hun, Choe. 2020a. 'He blames "evil" for South Korea's coronavirus surge. Officials blame him, The New York Times, 2.3.2020, <https://www.nytimes.com/2020/03/02/ world/asia/coronavirus-south-koreashincheonji.html>.

- - 2 2020b. " "Proselytizing robots": inside South Korean Church at outbreak's center', The New York Times, 10.3.2020, <https:// www.nytimes.com/2020/03/10/world/ asia/south-korea-coronavirus-shincheonji. html>.

- - . 2020c. 'Shadowy church is at center of coronavirus outbreak in South Korea, The New York Times, 21.2.2020, <https:// www.nytimes.com/2020/02/21/world/ asia/south-korea-coronavirus-shincheonji. html>.

Snow, David A., E. Burke Rochford, Steven K. Worden, and Robert D. Benford. 1986. 'Frame alignment processes, micromobilization, and movement participation', American Sociological Review 51(4): 46481, doi: <https://doi.org/10.2307/2095581>. Šorytè, Rosita. 2020. "We can lift this world while quarantined": Scientology and the 2020 pandemic', The Journal of CESNUR 4(4): 3-24, doi: <https://doi.org/10.26338/ tjoc.2020.4.4.1>.

Taylor, Bron. 2009. Deep Green Religion: Nature Spirituality and the Planetary Future (Berkeley: University of California Press).

The Garden. 2018. Facebook home page, <https://www.facebook.com/ groups/ $388751901308125 /$ permalink/973969156119727> (accessed 11.4.2021).

- - . 2021. 'The Garden: an off-grid intentional community', <https://thefreegarden. org $>$ (accessed 11.4.2021). 
Timberg, Craig, and Elizabeth Dwoskin. 2021. 'With Trump gone, QAnon groups focus fury on attacking coronavirus vaccines', The Washington Post, 11.3.2021, <https:// www.washington post.com/technology/2021/03/11/with-trump-gone-qanongroups-focus-fury-attacking-covid-vaccines/>.

TreeIsAlive.2021.<https://www.tiktok.com/@ treeisalive $>$ (accessed 11.4.2021).

Troeltsch, Ernst. 1931. The Social Teachings of the Christian Church (New York: Macmillan).

Weiner, Scott, Kirsten Lavery, and Dominic Nardi. 2020. 'The global response to the coronavirus: impact on religious practice and religious freedom, Factsheet Coronavirus, March 2020 (Washington, DC: United States Commission on Religious Freedom), $<$ https://www.uscirf.gov/sites/default/ files/2020\%2oFactsheet $\% 20$ Covid-19\%20 and\%2oFoRB.pdf $>$.

Wright, Mic. 2021. 'Trouble in The Garden: the rise and fall of the infamous TikTok commune, Input Magazine, <https://www. inputmag.com/culture/tik-tok-communeor-cat-eating-cult-garden-treeisalive> (accessed 11.4.2021).

Zeller, Benjamin E. 2010a. 'Inverted Orientalism, Vedic science, and the modern world: Bhaktivedanta and the International Society for Krishna Consciousness', in Handbook of Religion and the Authority of Science, eds. James R. Lewis and Olav Hammer (Leiden: Brill), 249-78.

- - 2010b. Prophets and Protons: New Religious Movements and Science in Late Twentieth-Century America (New York: New York University Press).

Zimmerman, Max. 2020. 'QAnon's rise in Japan shows conspiracy theory's global spread', Bloomberg, 29.11.2020, <https://www. bloomberg.com/news/articles/2020-11-29/ qanon-s-rise-in-japan-shows-conspiracy-theory-s-global-spread> (accessed 11.4.2020). 